\title{
Uusi kansainvälinen talousjärjestys
}

Toukokuussa 1978 tulee kuluneeksi neljä vuotta uuden kansainvälisen talousjärjestyksen eli 'UKTJ':n periaatteiden hyväksymisestä YK:n yleiskokouksen kuudennessa erityisistunnossa. Periaatteita on sittemmin täydennetty useissa muissa maailmanjärjestön päätöksissä. UKTJ on tullut pysyvästi laajan kansainvälisen keskustelun kohteeksi.

UKTJ:n periaatteiden tärkein sisältö on pyrkimys kehittää sellainen kansainvälisten taloussuhteiden järjestelmä, joka tekee mahdolliseksi maiden välisen eriarvoisuuden poistamisen ja takaa kehitysmaille poliittisen ja taloudellisen riippumattomuuden. Mikäli periaatteet toteutuisivat, tämä merkitsisi todella uudenlaista "talousjärjestystä".

Käytännössä UKTJ:n periaatteiden toteuttaminen on kuitenkin kohdannut lukuisia ongelmia. Osittain tämä perustuu siihen, että UKTJ:n käytäntö voidaan tulkita hyvin monella tavalla ja eri intressipiirien etujen mukaisesti. Voidaan jopa erottaa UKTJ:n "kapitalistinen" ja "sosialistinen" tulkinta.

Lisäksi UKTJ:n toteuttamisen edellytyksiä on ilmeisestikin heikentänyt kapitalistisen maail- mantalouden lama. Kun taistelu markkinaosuuksista on kiristynyt kehittyneiden kapitalististen maiden välillä, maat ovat tiukentaneet asennettaan kehitysmaiden vaatimuksiin nähden. Uutena piirteenä on myös ilmennyt pyrkimys nostaa kehitysmaiden joukosta esiin alueellisia kasvukeskuksia, joiden markkinoille suunnattaisiin osa kehittyneiden maiden ylituotannosta ja jotka siten saattaisivat toimia uuden nousun vauhdittajina. Kasvukeskuksia tukemalla pyritään myös poliittisesti hajottamaan kehitysmaiden rintamaa.

Seuraavassa julkaisemme kolmen turkulaisen tutkijan puheenvuorot uudesta talousjärjestyksèstä; nïssä käsitellään eri kannoilta UKTJ:n merkitystä ja toteuttamisedellytyksiä. Esko Antolan artikkelissa tarkastellaan niitä maailmantalouden muutosprosesseja, jotka ov't liittyneet UKTJ:n toteuttamiseen.. Jyrki Käkönen erittelee uuden talousjärjestyksen vaatimusta kansainvälisen luokkataistelun kannalta ja valottaa erityisesti imperislismin taktiikkaa sen suhteen. Jan-Otto Andersson käsittelee UKTJ:n merkitystä kansainvälisen työnjaon muuttumisessa. (Toim.). 